\title{
Expanded redox accessibility via ligand substitution in an octahedral Fe6Br6 cluster
}

\section{Citation}

Harris, T. David, Qinliang Zhao, Raúl Hernández Sánchez, and Theodore A. Betley. 2011. "Expanded Redox Accessibility via Ligand Substitution in an Octahedral Fe6Br6 Cluster." Chemical Communications 47, no. 22: 6344-6346.

\section{Published Version}

doi:10.1039/c1cc11561h

\section{Permanent link}

http://nrs.harvard.edu/urn-3:HUL.InstRepos:13041332

\section{Terms of Use}

This article was downloaded from Harvard University's DASH repository, and is made available under the terms and conditions applicable to Other Posted Material, as set forth at http:// nrs.harvard.edu/urn-3:HUL.InstRepos:dash.current.terms-of-use\#LAA

\section{Share Your Story}

The Harvard community has made this article openly available.

Please share how this access benefits you. Submit a story.

\section{Accessibility}




\title{
Expanded redox accessibility via ligand substitution in an octahedral $\mathrm{Fe}_{6} \mathrm{Br}_{6}$ cluster $\dagger$
}

\author{
T. David Harris, Qinliang Zhao, Raúl Hernández Sánchez and Theodore A. Betley*
}

Received 17th March 2011, Accepted 15th April 2011

DOI: $10.1039 / \mathrm{clcc11561h}$

Oxidation of the nominally all-ferrous hexanuclear cluster $\left({ }^{\mathrm{H}} \mathrm{L}\right)_{2} \mathrm{Fe}_{6}$ with six equivalents of ferrocenium in the presence of bromide ions results in a six-electron oxidation of the $\mathrm{Fe}_{6}$ core to afford the nominally all-ferric cluster $\left({ }^{\mathrm{H}} \mathrm{L}\right)_{2} \mathrm{Fe}_{6} \mathrm{Br}_{6}$. The hexabromide cluster is also structurally characterized in a $4+$ core oxidation state. A structural comparison of these two clusters provides an insight into the $\mathrm{Fe}_{6}$ core electronic structure.

Multielectron redox processes are mediated in nature through polynuclear transition metal clusters that comprise the active sites of proteins. ${ }^{1-4}$ Importantly, these clusters self-assemble and function according to the template provided by the protein superstructure. In view of these principles, we have set out to design modular ligand scaffolds that bind metal ions in a proximal arrangement, such that the metal-metal interactions result in a common delocalized electron reservoir shared by the close metal centers. Ultimately, this delocalized polynuclear core can potentially be exploited to drive multielectron reaction chemistry. Toward this end, we recently reported the synthesis of a hexaamine ligand, ${ }^{\mathrm{H}} \mathrm{LH}_{6}$, that, upon deprotonation, readily binds three metal ions in a vicinal trigonal planar arrangement. ${ }^{5}$ Subsequently, we demonstrated that, in the absence of phosphine ancillary ligands, two $\left({ }^{\mathrm{H}} \mathrm{L}\right) \mathrm{Fe}_{3}$ units can dimerize to generate the all-ferrous octahedral cluster $\left({ }^{\mathrm{H}} \mathrm{L}\right)_{2} \mathrm{Fe}_{6} \cdot{ }^{6}$ Remarkably, this cluster can readily be oxidized and reduced, enabling clean isolation of the electron-transfer series $\left[\left({ }^{\mathrm{H}} \mathrm{L}\right)_{2} \mathrm{Fe}_{6}(\mathrm{NCMe})_{x}\right]^{n+}(n=-1,0,1$, $2,3,4)$. Structural analysis of this series, in conjunction with Mössbauer spectroscopy and magnetic susceptibility measurements, indicate a delocalized electronic structure. Finally, NMR and Mössbauer spectroscopy suggest that a hexacationic cluster can be generated for short periods of time using strong oxidants, such as $\mathrm{NO}^{+}$. However, this unstable species rapidly decomposes to the tetracationic cluster, $\left[\left({ }^{\mathrm{H}} \mathrm{L}\right)_{2} \mathrm{Fe}_{6}(\mathrm{NCMe})_{6}\right]^{4+}$, along with a mixture of other multinuclear iron complexes and the free ${ }^{\mathrm{H}} \mathrm{LH}_{6}$ ligand.

\section{Department of Chemistry and Chemical Biology}

Harvard University, CambridgeMassachusetts 02138, USA.

E-mail: betley@chemistry.harvard.edu

$\dagger$ Electronic supplementary information (ESI) available: Experimental details, crystal packing diagram of $\mathbf{1}$, X-ray crystal structure of $\mathbf{2}$, Mössbauer spectrum of $\mathbf{1}$, tables of crystallographic data for $\mathbf{1}$ and $\mathbf{2}$, and X-ray crystallographic files (CIF) for $\mathbf{1}$ and 2. CCDC 818032 and 818033. For ESI and crystallographic data in CIF or other electronic format see DOI: $10.1039 / \mathrm{clcc} 11561 \mathrm{~h}$
In order to extend the redox chemistry of the $\left({ }^{\mathrm{H}} \mathrm{L}\right)_{2} \mathrm{Fe}_{6}$ platform, with a particular emphasis on accessing higher oxidation states, we have begun to explore the coordination chemistry of these clusters. As a first approach, simple substitution reactions, where the bound NCMe ligands are replaced with monoanionic ligands, are being explored. Here, the presence of up to six monoanionic ligands will dramatically lower the overall cluster charge of the molecule, thereby giving rise to a cathodically shifted redox window and potentially granting access to novel reactivity. Herein, we report the preparation of the nominally all-ferric cluster $\left({ }^{\mathrm{H}} \mathrm{L}\right)_{2} \mathrm{Fe}_{6} \mathrm{Br}_{6}(\mathbf{1})$, which is cleanly isolated via a six-electron oxidation of the all-ferrous $\left({ }^{\mathrm{H}} \mathrm{L}\right)_{2} \mathrm{Fe}_{6}$ by the mild oxidant ferrocenium ion, in the presence of bromide ions. In addition, the reaction of bromide with $\left[\left({ }^{\mathrm{H}} \mathrm{L}\right)_{2} \mathrm{Fe}_{6}(\mathrm{NCMe})_{6}\right]^{4+}$ affords the cluster $\left[\left({ }^{\mathrm{H}} \mathrm{L}\right)_{2} \mathrm{Fe}_{6} \mathrm{Br}_{6}\right]^{2-}$, which features a tetracationic $\left[\left({ }^{\mathrm{H}} \mathrm{L}\right)_{2} \mathrm{Fe}_{6}\right]^{4+}$ core.

Treatment of $\left({ }^{\mathrm{H}} \mathrm{L}\right)_{2} \mathrm{Fe}_{6}$ with six equivalents each of $\left[\mathrm{Cp}_{2} \mathrm{Fe}\right]\left(\mathrm{PF}_{6}\right)$ and $\left(\mathrm{Bu}_{4} \mathrm{~N}\right) \mathrm{Br}$ in acetonitrile results in the rapid precipitation of $\mathbf{1}$ from solution as a black amorphous solid in high yield (see Scheme 1). The zero-field ${ }^{57} \mathrm{Fe}$ Mössbauer spectrum of 1 (see Fig. S1 at $100 \mathrm{~K}$, displays a single, symmetric quadrupole doublet with an isomer shift of $\delta=0.37 \mathrm{~mm} \mathrm{~s}^{-1}$ and a quadrupole splitting of $\left|\Delta E_{\mathrm{Q}}\right|=2.78 \mathrm{~mm} \mathrm{~s}^{-1}$. These values are in close agreement with those obtained for the related short-lived cluster $\left[\left({ }^{\mathrm{H}} \mathrm{L}\right)_{2} \mathrm{Fe}_{6}(\mathrm{NCMe})_{6}\right]^{6+}$, which also features an $\left[\left({ }^{\mathrm{H}} \mathrm{L}\right)_{2} \mathrm{Fe}_{6}\right]^{6+}$ core $\left(\delta=0.37 \mathrm{~mm} \mathrm{~s}^{-1},\left|\Delta E_{\mathrm{Q}}\right|=2.60 \mathrm{~mm} \mathrm{~s}^{-1}\right){ }^{6}$

Owing to the propensity of $\mathbf{1}$ to rapidly precipitate from solution, along with its general insolubility in organic solvents, a layering technique was employed to grow single crystals of $\mathbf{1}$. The layering, composed of an acetonitrile solution containing $\left[\left({ }^{\mathrm{H}} \mathrm{L}\right)_{2} \mathrm{Fe}_{6}(\mathrm{NCMe})_{6}\right]^{4+}{ }^{6}$ and $\left[\mathrm{Cp}_{2} \mathrm{Fe}\right]^{+}$on top of an aqueous layer containing $\mathrm{Br}^{-}$ion, produced black, plate-shaped

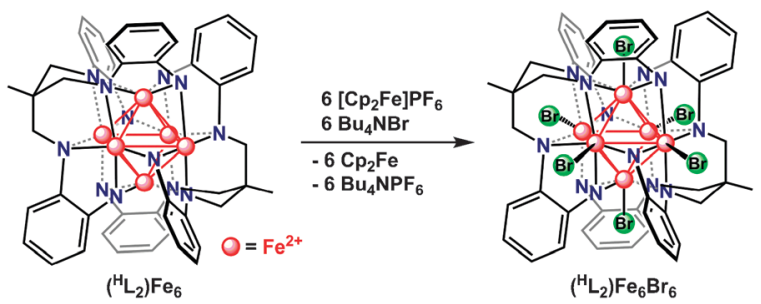

Scheme 1 Oxidation of the all-ferrous cluster $\left({ }^{\mathrm{H}} \mathrm{L}\right)_{2} \mathrm{Fe}_{6}$ in the presence of bromide to give the all-ferric cluster $\left({ }^{\mathrm{H}} \mathrm{L}\right)_{2} \mathrm{Fe}_{6} \mathrm{Br}_{6}$. 


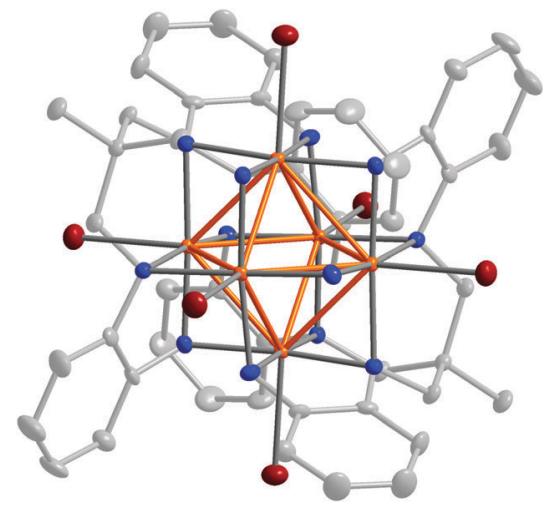

Fig. 1 The crystal structure of $\left({ }^{\mathrm{H}} \mathrm{L}\right)_{2} \mathrm{Fe}_{6} \mathrm{Br}_{6}$, with ellipsoids shown at the $50 \%$ probability level. Orange, maroon, gray and blue ellipsoids represent $\mathrm{Fe}, \mathrm{Br}, \mathrm{C}$, and $\mathrm{N}$ atoms, respectively; $\mathrm{H}$ atoms are omitted for clarity. The periphery of the $\left[{ }^{\mathrm{H}} \mathrm{L}\right]^{6-}$ ligand is transparent to aid visualization of the octahedral $\mathrm{Fe}_{6}$ core. The single Fe center in the asymmetric unit resides on a site of $S_{6}$ symmetry. Selected mean interatomic distances $(\AA)$ and angles (deg): $\mathrm{Fe}-\mathrm{N}$ 1.97(1), $\mathrm{Fe}-\mathrm{Br}$ 2.445(2), Fe-Fe 2.713(3), trans-Fe ‥Fe 3.837(2), Fe-N-Fe 87.1(3).

crystals of 1 over the course of two weeks. $\ddagger$ Notably, omitting $\left[\mathrm{Cp}_{2} \mathrm{Fe}\right]^{+}$from the layering still produces crystals of $\mathbf{1}$, suggesting that ambient oxygen also facilitates the two-electron oxidation. The structure of $\mathbf{1}$, depicted in Fig. 1, consists of an edge-bridged octahedral $\mathrm{Fe}_{6}$ core supported by two trinucleating $\left[{ }^{\mathrm{H}} \mathrm{L}\right]^{6-}$ ligands and six Fe-bound bromide ions (see also Fig. S2†). Each Fe center resides in a square pyramidal coordination environment, with four amide nitrogen atoms forming the base of the plane and a bromide ligand occupying the apical position. The mean $\mathrm{Fe}-\mathrm{Fe}$ distance within the $\mathrm{Fe}_{6}$ core is 2.713(3) $\AA$, longer than those observed in $\left[\left({ }^{\mathrm{H}} \mathrm{L}\right)_{2} \mathrm{Fe}_{6}(\mathrm{NCMe})_{x}\right]^{n+}$ ( $n=-1-4 ; 2.5804(11)-2.7040(13) \AA)$ (see Tables S1 and $\mathrm{S} 2 \dagger)$. In addition, the $\mathrm{Fe}_{6}$ core subtends an approximate $\mathrm{Fe}_{6}$ octahedron of volume 9.413(4) $\AA^{3}$. Finally, the cluster features an $\mathrm{Fe}-\mathrm{Br}$ distance of $2.445(2) \AA$. We note that while a number of octahedral $\mathrm{M}_{6} \mathrm{X}_{6}\left(\mathrm{M}=\mathrm{Cu},{ }^{7} \mathrm{Zr},{ }^{8} \mathrm{Nb},{ }^{9} \mathrm{Mo},{ }^{10} \mathrm{Ta},{ }^{11} \mathrm{~W},{ }^{12} \mathrm{Re}^{13}\right)$ clusters have been previously isolated, to the best of our knowledge, compound 1 represents the first example of a structurally characterized octahedral $\mathrm{M}_{6} \mathrm{X}_{6}$ cluster comprised of a Group VIII metal core not supported by an interstitial oxygen atom. ${ }^{14,15}$

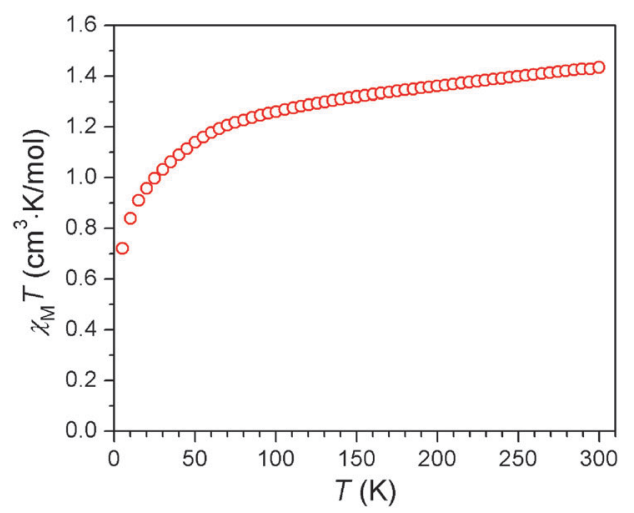

Fig. 2 Variable-temperature dc magnetic susceptibility data for 1, collected under an applied field of $1 \mathrm{~T}$.

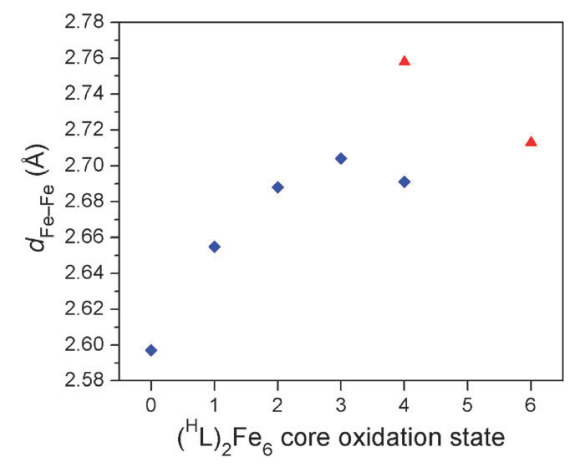

Fig. 3 The dependence of the mean $\mathrm{Fe}-\mathrm{Fe}$ distance on the $\mathrm{Fe}_{6}$ core oxidation state in the clusters $\left[\left({ }^{\mathrm{H}} \mathrm{L}\right)_{2} \mathrm{Fe}_{6}(\mathrm{NCMe})_{x}\right]^{n+}(n=0-4$, blue diamonds) and $\left[\left({ }^{\mathrm{H}} \mathrm{L}\right)_{2} \mathrm{Fe}_{6} \mathrm{Br}_{6}\right]^{n-}(n=0,2$, red triangles $)$.

The variable-temperature dc magnetic susceptibility data for 1 , collected on a powder sample under an applied field of $1 \mathrm{~T}$, is depicted in Fig. 2 as a plot of $\chi_{\mathrm{M}} T v s$. T. As the temperature is decreased from $300 \mathrm{~K}$, the data undergo a slight, near-linear decrease down to $c a$. $100 \mathrm{~K}$, with an average value of $\chi_{\mathrm{M}} T=1.36 \mathrm{~cm}^{3} \mathrm{~K} \mathrm{~mol}^{-1}$, followed by a precipitous decline below $100 \mathrm{~K}$. Previous work with the $\left[\left({ }^{\mathrm{H}} \mathrm{L}\right)_{2} \mathrm{Fe}_{6}(\mathrm{NCMe})_{x}\right]^{n+}$ series demonstrated that the $\mathrm{Fe}_{6}$ cluster core can best be described by a delocalized electronic structure, where a spin ground state remains isolated from the excited states up to at least $300 \mathrm{~K}^{6}$ Accordingly, the average value of $\chi_{\mathrm{M}} T=1.36 \mathrm{~cm}^{3} \mathrm{~K} \mathrm{~mol}^{-1}$ obtained for $\mathbf{1}$ in the range $100-300 \mathrm{~K}$ is consistent with the exclusive thermal population of an $S=1$ spin ground state, with a value of $g$ slightly larger than 2.00 and a small temperature-independent paramagnetic contribution to the susceptibility. The precipitous decline below $100 \mathrm{~K}$ likely results from significant zero-field splitting, Zeeman splitting, and/or weak intermolecular antiferromagnetic exchange interactions.

Attempts to cleanly isolate compounds containing the hexabromide cluster in other oxidation states have thus far produced mixtures of insoluble products, possibly containing a distribution of redox isomers bearing a range of ligand combinations. Nevertheless, treatment of the cationic cluster $\left[\left({ }^{\mathrm{H}} \mathrm{L}\right)_{2} \mathrm{Fe}_{6}(\mathrm{NCMe})_{6}\right]^{4+}$ with a saturated DMF solution of $\left(\mathrm{Ph}_{4} \mathrm{P}\right) \mathrm{Br}$ can stabilize the cluster $\left[\left({ }^{\mathrm{H}} \mathrm{L}\right)_{2} \mathrm{Fe}_{6} \mathrm{Br}_{6}\right]^{2-}$ in solution for periods of several hours. Indeed, one such reaction resulted in a mixture of amorphous solid and black, block-shaped crystals of $\left(\mathrm{Ph}_{4} \mathrm{P}\right)_{2}\left[\left({ }^{\mathrm{H}} \mathrm{L}\right)_{2} \mathrm{Fe}_{6} \mathrm{Br}_{6}\right]$. 2DMF (2), suitable for single-crystal X-ray diffraction. $\S$ The structure of $\mathbf{2}$ closely resembles that of $\mathbf{1}$, with an octahedral $\mathrm{Fe}_{6}$ core ligated by two $\left[{ }^{\mathrm{H}} \mathrm{L}\right]^{6-}$ ligands and six bromide ions (see Fig. S3†). The most notable difference is that the core is significantly expanded compared to that of $\mathbf{1}$, with a mean $\mathrm{Fe}-\mathrm{Fe}$ distance of 2.758(2) $\AA$ and a volume of 9.885(3) $\AA^{3}$ (see Tables S3 and $\mathrm{S} 4 \dagger$ ). This volumetric increase represents a core expansion of $5 \%$ in moving from $\mathbf{1}$ to $\mathbf{2}$. In addition, the structure of 2 features a mean $\mathrm{Fe}-\mathrm{Br}$ distance of 2.504(1), which is considerably longer than that observed in $\mathbf{1}$. This elongated distance is reflective of the lower positive charge $(4+v s .6+$ for $\mathbf{1})$ that is delocalized about the $\left[\left({ }^{\mathrm{H}} \mathrm{L}\right)_{2} \mathrm{Fe}_{6}\right]^{n+}$ core.

Comparing the $\mathrm{Fe}-\mathrm{Fe}$ distances and core volumes in $\mathbf{1}$ and $\mathbf{2}$ to those observed in the $\left[\left({ }^{\mathrm{H}} \mathrm{L}\right)_{2} \mathrm{Fe}_{6}(\mathrm{NCMe})_{x}\right]^{n+}$ series provides some insight into the $\mathrm{Fe}_{6}$ core electronic structure and how it is 
perturbed by bromide versus acetonitrile ligands. In the $\left[\left({ }^{\mathrm{H}} \mathrm{L}\right)_{2} \mathrm{Fe}_{6}(\mathrm{NCMe})_{x}\right]^{n+}$ series, the mean $\mathrm{Fe}-\mathrm{Fe}$ distance increases linearly with increasing charge from the all-ferrous cluster to the tricationic cluster, which is likely to be a result of the increasing electronic population of antibonding orbitals. However, oxidation of the tricationic to the tetracationic species results in a decrease in the number of electrons that reside in antibonding orbitals and, consequently, a decrease in the mean $\mathrm{Fe}-\mathrm{Fe}$ distance. ${ }^{6}$ Accordingly, one would expect the mean $\mathrm{Fe}-\mathrm{Fe}$ distance to decrease further upon moving from $\left[\left({ }^{\mathrm{H}} \mathrm{L}\right)_{2} \mathrm{Fe}_{6}(\mathrm{NCMe})_{6}\right]^{4+}$ to $\left[\left({ }^{\mathrm{H}} \mathrm{L}\right)_{2} \mathrm{Fe}_{6}(\mathrm{NCMe})_{6}\right]^{6+}$. Unfortunately, the absence of a crystal structure of the hexacationic species has precluded validation of this hypothesis. Nevertheless, comparison of structural data for $\mathbf{1}$ and $\mathbf{2}$ reveals that an analogous contraction does indeed occur in moving from a tetra- to a hexacationic $\left.\left[{ }^{\mathrm{H}} \mathrm{L}\right)_{2} \mathrm{Fe}_{6}\right]^{n+}$ core. This observation suggests that the increase in oxidation state removes electrons from antibonding orbitals. Additionally, the increased mean $\mathrm{Fe}-\mathrm{Fe}$ distance in 2 relative to $\left[\left({ }^{\mathrm{H}} \mathrm{L}\right)_{2} \mathrm{Fe}_{6}(\mathrm{NCMe})_{6}\right]^{4+}$ likely stems from the negative charges of the weaker ligand field bromide ions, which lead to an increase in the energies of the antibonding frontier orbitals.

The foregoing results demonstrate the ability of bromide ligands to enable facile six-electron oxidation of the all-ferrous cluster $\left({ }^{\mathrm{H}} \mathrm{L}\right)_{2} \mathrm{Fe}_{6}$ to the all-ferric cluster $\left({ }^{\mathrm{H}} \mathrm{L}\right)_{2} \mathrm{Fe}_{6} \mathrm{Br}_{6}$, requiring only the mild oxidant $\left[\mathrm{Cp}_{2} \mathrm{Fe}\right]^{+}$. This compound introduces an avenue through which to extend the redox accessibility in $\left({ }^{\mathrm{H}} \mathrm{L}\right)_{2} \mathrm{Fe}_{6}$ clusters, which could previously only be cleanly isolated with up to tetracationic $\left[\left({ }^{\mathrm{H}} \mathrm{L}\right)_{2} \mathrm{Fe}_{6}\right]^{4+}$ cores. Additionally, single crystals containing the electron-transfer isomer $\left[\left({ }^{\mathrm{H}} \mathrm{L}\right)_{2} \mathrm{Fe}_{6} \mathrm{Br}_{6}\right]^{2-}$ were obtained through reaction of $\left[\left({ }^{\mathrm{H}} \mathrm{L}\right)_{2} \mathrm{Fe}_{6}(\mathrm{NCMe})_{6}\right]^{4+}$ with bromide. Work is underway to explore the coordination chemistry of the $\mathrm{Fe}_{6}$ platform by preparing related clusters featuring other monoanionic ligands. Comparing data from physical measurements, such as Mössbauer spectroscopy and magnetic susceptibility, across a series of these clusters will enable a systematic examination of the effects of ligand strength and bonding interactions on the $\mathrm{Fe}_{6}$ core electronic structure.

This work was supported by Harvard University. We thank Prof. R. H. Holm for generous use of his Mössbauer spectrometer.

\section{Notes and references}

$\ddagger \mathrm{X}$-ray analysis for $\mathbf{1}\left(\mathrm{C}_{46} \mathrm{H}_{48} \mathrm{Br}_{6} \mathrm{Fe}_{6} \mathrm{~N}_{12}, \mathrm{fw}=1583.45\right)$ at $T=100 \mathrm{~K}$ : space group $R \overline{3}, a=b=12.475(4) \AA, c=26.820(7), V=3614.9(18) \AA^{3}$, $Z=3, d_{\text {calc }}=2.182 \mathrm{~g} \mathrm{~cm}^{-1}, R_{1}=0.0485, w R_{2}=0.1469$.

$\S$ X-ray analysis of $2\left(\mathrm{C}_{100} \mathrm{H}_{102} \mathrm{Br}_{6} \mathrm{Fe}_{6} \mathrm{~N}_{14} \mathrm{O}_{2} \mathrm{P}_{2}\right.$, fw $\left.=2408.41\right)$ at

$T=100 \mathrm{~K}$ : space group $P \overline{1}, a=12.8566(13) \AA, b=13.5153(14) \AA$, $c=15.7219(16) \AA, \alpha=91.218(2)^{\circ}, \beta=110.219(2)^{\circ}, \gamma=113.491(2)$, $V=2310.6(4) \AA^{3}, Z=1, d_{\text {calc }}=1.731 \mathrm{~g} \mathrm{~cm}^{-1}, R_{1}=0.0369, w R_{2}=0.0854$.

1 J. W. Peters, M. H. B. Stowell, S. M. Soltis, M. G. Finnegan, M. K. Johnson and D. C. Rees, Biochemistry, 1997, 36, 1181; H. Beinert, R. H. Holm and E. Münck, Science, 1997, 277, 653; S. M. Mayer, D. M. Lawson, C. A. Gormal, S. M. Roe and B. E. Smith, J. Mol. Biol., 1999, 292, 871; O. Einsle, F. A. Tezcan, S. Andrade, B. Schmid, M. Yoshida, J. B. Howard and D. C. Rees, Science, 2002, 297, 1696.

2 Y. Nicolet, C. Piras, P. LeGrand, C. E. Hatchikian and J. C. Fontecilla-Camps, Structure, 1999, 7, 13; D. J. Evans and C. J. Pickett, Chem. Soc. Rev., 2003, 32, 268.

3 K. Brown, K. Djinovic-Carugo, T. Haltia, I. Cabrito, M. Saraste, J. J. G. Moura, I. Moura, M. Tegoni and C. Cambillau, J. Biol. Chem., 2000, 275, 41133; K. Brown, M. Tegoni, M. Prudêncio,
A. S. Pereira, S. Besson, J. J. Moura, I. Moura and C. Cambillau, Nat. Struct. Biol., 2000, 7, 191; P. Chen, S. D. George, I. Cabrito, W. E. Antholine, J. G. Moura, I. Moura, B. Hedman, K. O. Hodgson and E. I. Solomon, J. Am. Chem. Soc., 2002, 124, 744.

4 J. H. A. Nugent, A. M. Rich and M. C. W. Evans, Biochim. Biophys. Acta, Bioenerg., 2001, 1503, 138; K. N. Ferreira, T. M. Iverson, K. Maghlaoui, J. Barber and S. Iwata, Science, 2004, 303, 1831; S. Iwata and J. Barber, Curr. Opin. Struct. Biol., 2004, 14, 447.

5 Q. Zhao and T. A. Betley, Angew. Chem., Int. Ed., 2011, 50, 709.

6 Q. Zhao, T. D. Harris and T. A. Betley, J. Am. Chem. Soc., DOI: $10.1021 / \mathrm{ja} 2015845$.

7 M. R. Churchill, S. A. Bezman, J. A. Osborn and J. Wormald, Inorg. Chem., 1972, 11, 1818; R. M. zu Kocker, A. Behrendt and K. Dehnicke, Z. Naturforsch., B: J. Chem. Sci., 1994, 49, 301; R. M. zu Kocker, K. Dehnicke and D. Fenske, Z. Naturforsch., B. J. Chem. Sci., 1994, 49, 987.

8 C. E. Runyan Jr. and T. Hughbanks, J. Am. Chem. Soc., 1994, 116, 7909; L. Chen, F. A. Cotton and W. A. Wojtczak, Inorg. Chim. Acta, 1996, 252, 239; L. Chen, F. A. Cotton, W. T. Klooster and T. F. Koetzle, J. Am. Chem. Soc., 1997, 119, 12175; X. Xie and T. Hughbanks, Inorg. Chem., 2002, 41, 1824; J. B. Willems, H. W. Rohm, C. Geers and M. Kockerling, Inorg. Chem., 2007, 46, 6197.

9 B. Yan, H. Zhou and A. Lachgar, Inorg. Chem., 2003, 42, 8818; R. A. Field, D. L. Kepert, B. W. Robinson and A. H. White, J. Chem. Soc., Dalton Trans., 1973, 1858; F. W. Koknat and R. E. McCarley, Inorg. Chem., 1974, 13, 295.

10 J. B. Michel and R. E. McCarley, Inorg. Chem., 1982, 21, 1864; M. Ebihara, K. Isobe, Y. Sasaki and K. Saito, Inorg. Chem., 1992, 31, 1644; W. Preetz, K. Harder, H. G. von Schnering, G. Kliche and K. Peters, J. Alloys Compd., 1992, 183, 413; W. Preetz, D. Bublitz, H. G. von Schnering and J. Sassmanhausen, Z. Anorg. Allg. Chem., 1994, 620, 234.

11 A. Slougui, L. Ouahab, C. Perrin, D. Grandjean and P. Batail, Acta Crystallogr., Sect. C: Cryst. Struct. Commun., 1989, 45, 388; N. Brnicevic, S. Sirac, I. Basic, Z. Zhang, R. E. McCarley and I. A. Guzei, Inorg. Chem., 1999, 38, 4159; D. N. T. Hay, D. C. Swenson and L. Messerle, Inorg. Chem., 2002, 41, 4700.

12 T. C. Zietlow, W. P. Schaefer, B. Sadeghi, N. Hua and H. B. Gray, Inorg. Chem., 1986, 25, 2195; D. Venkataraman, L. L. Rayburn, L. I. Hill, S. Jin, A.-S. Malik, K. J. Turneau and F. J. DiSalvo, Inorg. Chem., 1999, 38, 828; M. Stallmann and W. Preetz, Z. Anorg. Allg. Chem., 2000, 626, 258; S. Tragl, M. Strobele, J. Glaser, C. Vicent, R. Llusar and H.-J. Meyer, Inorg. Chem., 2009, 48, 3825.

13 A. Penicaud, K. Boubekeur, P. Batail, E. Canadell, P. Auban-Senzier and D. Jerome, J. Am. Chem. Soc., 1993, 115, 4101; J.-C. Gabriel, K. Boubekeur and P. Batail, Inorg. Chem., 1993, 32, 2894; S. Uriel, K. Boubekeur, P. Batail, J. Orduna and E. Canadell, Inorg. Chem., 1995, 34, 5307; J. R. Long, L. S. McCarty and R. H. Holm, J. Am. Chem. Soc., 1996, 118, 4603; S. Uriel, K. Boubekeur, P. Batail and J. Orduna, Angew. Chem., Int. Ed. Engl., 1996, 35, 1544; E. G. Tulsky and J. R. Long, Inorg. Chem., 2001, 40, 6990; S. S. Yarovoi, Y. V. Mironov, S. F. Solodovnikov, Z. A. Solodovnikova, D. Y. Naumov and V. E. Fedorov, Koord. Khim., 2006, 32, 743; C. Guilbaud, A. Deluzet, B. Domercq, P. Molinie, C. Coulon, K. Boubekeur and P. Batail, Chem. Commun., 1999, 1867; Y. V. Mironov, V. E. Fedorov, M. A. Pell and J. A. Ibers, Zh. Strukt. Khim., 1998, 39, 746; S. Uriel, K. Boubekeur, P. Batail, J. Orduna and E. Canadell, Inorg. Chem., 1995, 34, 5307.

14 Examples of oxygen-centered $\mathrm{Fe}_{6} \mathrm{Cl}_{6}$ Clusters: A. Cornia, D. Gatteschi, K. Hegetschweiler, L. Hausherr-Primo and V. Gramlich, Inorg. Chem., 1996, 35, 4414; R. C. Finn and J. Zubieta, J. Cluster Sci., 2000, 11, 461; J. Spandl, M. Kusserow and I. Brudgam, Z. Anorg. Allg. Chem., 2003, 629, 968; G. Jiang, J. Bai, H. Xing, Y. Li and X. You, Cryst. Growth Des., 2006, 6, 1264.

15 Several $\mathrm{Fe}_{6} \mathrm{X}_{6}$ prismane clusters have been structurally characterized: S. Pohl and W. Saak, Angew. Chem., Int. Ed. Engl., 1984, 23, 907; M. G. Kanatzidis, W. R. Hagen, W. R. Dunham, R. K. Lester and D. Coucouvanis, J. Am. Chem. Soc., 1985, 107, 953; M. G. Kanatzidis, A. Salifoglou and D. Coucouvanis, J. Am. Chem. Soc., 1986, 25, 2460; B. S. Snyder and R. H. Holm, Inorg. Chem., 1988, 27, 2339. 